\title{
The Changes of the Entrepreneurial Identity: Case Study
} Cambios de la identidad emprendedora: caso de estudio

\author{
Alina Valencia \\ Autonomous University of Barcelona
}

\begin{abstract}
This research assumes the study of the construction and the changes in the identity of entrepreneurs based on the analysis of their personal and professional way and the influence of critical incidents and its changes based on Dialogical Self Theory (Hubert Hermans, Harry Kempen, Rens van Loon) leading to increase the quality of life and effectiveness of their business. We made a case-study with four entrepreneurs with less than one-year experience from different countries for six months the research used interview, mapping, journey plot, Personal Position Repertoire, and coaching. They showed a variety of scenarios of forming the entrepreneurial identity in typical contexts, including family business or starting their own business after working for the company or freelance. We observed that the implication of the tools used in the psychological practice helped to make the process systematic, clear and multilevel showing the progress of the participants on every stage as their personal and professional achievements.
\end{abstract}

Keywords: Social construction of identity; Entrepreneurship; Critical incidents; I-positions

\section{Resumen}

Esta investigación asume el estudio de la construcción y los cambios en la identidad de los emprendedores con base en el análisis personal y profesional y la influencia de incidentes críticos y sus cambios basados en la Teoría del Self Dialogical (Hubert Hermans, Harry Kempen, Rens van Loon). Hicimos un estudio de caso de seis meses con cuatro empresarios con menos de un año de experiencia, la investigación utilizó entrevistas, mapeo, trama de viaje, repertorio de posición personal y entrenamiento. Mostraron la variedad de escenarios para formar la identidad empresarial en contextos típicos, incluyendo negocios familiares, comenzar su propio negocio después de trabajar para una empresa o por cuenta propia. Observamos que la implicación de las herramientas utilizadas en la práctica psicológica ayudó a que el proceso fuera sistemático, claro y multinivel, mostrando el progreso de los participantes en cada etapa, así como sus propios logros personales y profesionales.

Palabras clave: Construcción de la identidad social; emprendimiento, Incidentes criticos; Yo-posiciónes 


\section{INTRODUCTION}

Becoming an entrepreneur is always a life choice; spontaneous or planned. The recent model of the motivation of becoming an entrepreneur distinguishes the tolerance for risk, self-efficacy, and perceived net desirability (Segal, Borgia \& Schoenfeld, 2005). In any case, it influences the identity of the person provoking not only changes in the way of life but most of all, in the identity. Looking at these changes from the focus of psychology of identity can become a clue to increasing the quality of life for entrepreneurs and the effectiveness of their business.

Our investigation assumes the profound research of the construction of the identity of entrepreneurs based on the analysis of their personal and professional way and the influence of critical incidents on its changes. We target to realize this research not just as an empirical part but as a start of the training and valuable time of self-development for the participants.

\section{FRAMEWORK}

As the essential elements of the study, we can highlight the model of the entrepreneurial identity according to the Dialogical Self Theory (Hermans, 2006, 2008; Hermans \& Hermans-Konopka, 2010; Hermans \& Gieser, 2011; Hermans, Kempen \& van Loon, 1992) and Dialogical Leadership (van Loon, 2010, 2018); importance of Critical Incidents for forming the identity (Monereo, 2015, 2019). The entrepreneurial identity is understood as a complex multilevel structure, including a unique group of I-positions, proposing different concepts or roles, feelings about entrepreneurship and strategies and it is constructed in the inner dialogue with other voices (Monereo, Weise \& Alvarez, 2013). "I-position" is composed of three factors: a "self-concept" (e.g., "me as a head of the company," "me as an expert," "me as a manager,") a strategy (e.g., a strategy of avoiding risks, a strategy of collaboration), and emotional aspect (it is about how we feel ourselves in these I-positions).

We can say no one is using just one I-position, it is sufficient to adapt the Ipositions according to the situation, place and time, but the study shows that the entrepreneurs mostly have one dominating I-position which is used as a strategy or reaction on critical incidents or during their everyday professional life. According to the DST, it is called "core position," which becomes a central position on which other positions depend (Hermans, 2018).

We observe ourselves through internal dialogue and reflection, analyze, and create awareness of own professional identity of an entrepreneur which is formed by different I-positions, for example, as a "team leader," "innovator," 
owner." Thus, the I-position always includes a way of interpreting reality, for example, of the past event, the ways to influence the situation, the emotional perception of the situation (Monereo, 2015). Therefore, I-professional position is a unique group of concepts, strategies, and feelings/sensations, expressed in terms of the voice in the dialogue with other voices (Monereo et al., 2013).

To provide constant productivity, the entrepreneur needs to be moving flexibly between the roles, styles and strategies and "think out of the box" which is guaranteed by the possibility of using different I-positions in proper situations and for solving problems (van Loon, 2018). As these problems can be very different, they can even put the entrepreneur into crisis, acting as critical incidents. As a critical incident, we assume any incident significant to a person and having a high impact on his personal or professional life because it puts a person into the crisis (Monereo, 2015).

\section{SPECIFIC SUBJECT REVISION}

Earlier we have created and expanded the questionnaire "Survey for Entrepreneurs on Critical Incidents" which involved 420 participants, entrepreneurs from different EU countries. Situations proposed in the survey all mostly deal with psychological aspects of entrepreneurial behavior. The main results confirm the high importance of critical incidents for the formation of entrepreneurial identity and existence of four identity profiles which lead to different types of I-positions that entrepreneurs choose and acting strategies according to these positions in a real business environment. Using the results of the previous research we highlighted four main entrepreneurial I-positions:

- "Leader", focused on his team, the inspirer, the creator, and the implementer of vision and strategy.

- "Innovator", characterized by innovative thinking, the creation of innovative products, measuring success by the impact of their products or services on the development of mankind. Always tends to invent and design.

- "Fighter" trusts only in himself and presents himself as a general part of his company. Constantly struggling to survive in a competitive market, scared to lose control and prefer to use the strategies of building a strong hierarchy.

- "Opportunist", a constant resource finder, the "seller", always looks for new opportunities in the market and constantly searching for new resources for their business in different spheres. Decision making is focused on the market and customers' opinions (Valencia \& Monereo, 2019). 
Four types of entrepreneurial I-positions mentioned above became a basement of this study helping to analyze the process of the construction of entrepreneurial identity and the changes in the I-positioning of the participants.

General target of the research is to study the changes in I-positions during the process of the construction of the identity of young entrepreneurs based on the analysis of their personal and professional way and the influence of critical incidents on its forming.

\section{SAMPLE}

To achieve a general target of the research we have chosen four participants according to the following criteria: they were all the representatives of different types of entrepreneurial I-positions according to the data obtained within the previous study, all have less than one year of experience in business and should have been eager to participate and interest in forming their entrepreneurial identity. We have sent the invitations for the participation to twentyfour participants (six representatives of each group) and then chose four of them from those who confirmed the possibility to participate in the program, according to their motivation and focus on self-development.

\begin{tabular}{|c|c|c|c|c|}
\hline & 1 & 2 & 3 & 4 \\
\hline Participant & L. & J. & $\mathrm{H}$. & N. \\
\hline Country & Russia & Ireland & Portugal & Spain \\
\hline Gender & Female & Male & Male & Female \\
\hline Age & 24 & 38 & 36 & 33 \\
\hline Business & Agriculture, services & Biotech & IT & Personal services \\
\hline DEIP* & Leader & Innovator & Fighter & Opportunist \\
\hline Case & $\begin{array}{l}\text { L. is involved in family } \\
\text { business and trying to } \\
\text { find herself as an en- } \\
\text { trepreneur and to find } \\
\text { her place in her par- } \\
\text { ent's company. }\end{array}$ & $\begin{array}{l}\text { Firstly, J. was working } \\
\text { for the company, but } \\
\text { after participating and } \\
\text { winning some business } \\
\text { contests started his } \\
\text { own business and got } \\
\text { the investment. Main } \\
\text { goal - a creation of a } \\
\text { large international in- } \\
\text { novational company. }\end{array}$ & $\begin{array}{l}\text { H. started the compa- } \\
\text { ny to be independent } \\
\text { and to prove to him- } \\
\text { self and his family, he } \\
\text { can achieve a lot. At } \\
\text { the beginning of his } \\
\text { business experience he } \\
\text { had some challenges, } \\
\text { so now his goal is to } \\
\text { develop his entrepre- } \\
\text { neurial skills. }\end{array}$ & $\begin{array}{l}\mathrm{N} \text {. just started her } \\
\text { business and wants to } \\
\text { develop her business } \\
\text { ideas, to realize them } \\
\text { on practice and find } \\
\text { herself as an entre-- } \\
\text { preneur. }\end{array}$ \\
\hline
\end{tabular}

*DEIP - dominating entrepreneurial I-position

Table 1. General characteristics of the participants 
All four cases represent different contexts of forming the entrepreneurial identity leading to understanding the variety of frequently seen backgrounds of becoming an entrepreneur. All of them were entrepreneurs of different European countries under forty years old with a different background. About the level of education, L., H., and N. have a Master's degree, J. has a Doctor's degree. The general characteristics of the participants are presented in Table 1.

\section{EMPIRICAL DESIGN}

The study is based on profound case analysis. For our research the case study was chosen as the most valuable instrument proposing a comparison and reflection, helping the researcher not only to study the object but also to see the formation of the object (Bartlett \& Vavrus, 2017).

The research included profound work with each participant targeting to understand the process of construction of entrepreneurial identity.

For each participant, we obtained the complete profile applying the chosen tools, such as structured interview report, generalized I-position mapping and personal position repertoire matrix, journey plot scheme with fundamental incidents (negative or positive events) which could lead the participant to becoming entrepreneur.

The use of the tools helped us to understand, widely describe and to see the main tendencies of the targeting group.

\section{REGISTRATION AND ANALYSIS INSTRUMENTS}

The methodology of this study includes the following instruments:

- Interview (dedicated to the vision of entrepreneurship, the participants' role and mission in the profession, critical incidents, and life events that were meaningful for choosing entrepreneurship as their professional career).

- Mapping is used as a tool for visualizing the complex construction of identity as a combination of I-positions. It involves a graphical representation of the critical stages or periods in the person's life (both positive and negative but influencing their decision to become the entrepreneur) through a sinuous line, with distinct curves (Burnard, 2012; Monereo, 2017; Ruohotie-Lyhty, 2013).

Moreover, this instrument is of high importance for the basic structuring of the self-perception of a participant at the beginning of his entrepreneur's career. According to our practical experience, it is a valuable tool not only for the re- 
searcher but for the participant. The mapping was used for the understanding of the milestones in their lives, which led to the decision to start their own business.

Journey plot was held in the form of the questionnaire which was forwarded to each participant at the beginning of the research. The progressive Journey plot in our study represents the participant's trajectory within six months of the study (the participants filled in the form every week and then each month). One scale showed the timeline, and another showed the emotional impact of the events which the participant found as the critical incidents during the corresponding month. The emotional impact scale has the gradation from -2 , most negative event to +2 , most positive event and is measured by each participant for each particular case. Journey plot as an instrument targets to understand critical incidents which happen during the everyday entrepreneur's life and lead to the forming I-positions, changing them and understanding the full range of different I-positions presented in the identity revealing the whole matrix of personal position repertoire.

Personal Position Repertoire (PPR) is one of the modern methods in practical psychology which was extensively described by Hubert Hermans $(2001 ; 2016)$. It includes proposing the list of internal and external positions to the participant; then the participant is invited to add other positions related to his or her life. As a result, we see a matrix of internal and external positions, with the prominence ratings in the entries (Kluger, Nir \& Kluger, 2008).

- PPR is used as a research method as well as a counselling method helping the client to analyze and articulate the problem, to understand his identity much more profound and to see the correlation between internal and external positions as it becomes much easier for the client when the specialist already formulates the positions according to the research of his identity. So, the researcher can observe the evolution of the leading identity positions through conflictive and non-conflictive relationships, promoted by some relevant incidents (Monereo, 2017).

In our research, PPR is used as an assessment instrument device for the investigation of content and organization of position repertoire of young entrepreneurs, which is presented in the form of individual repertoire matrix of each participant, which shows the prominence of a range of internal positions in relation to a range of external positions.

- Elements of coaching were included in the interaction with each participant. According to the approach of Dialogical Leadership, we applied the main principles of dialogue during each coaching session: listening, re- 
specting, suspending judgment, and voicing (van Loon, 2010). The coaching approach in our research was used with the target to reach close relationship and atmosphere of trust and comfort as the research assumes a profound study of the personal way involving emotional sphere and biographical data. Such atmosphere was provided by high attention to the participants, their problem and non-judgement. Besides that, the participants were highly motivated and were said from the beginning that all the instruments applied, and meetings arranged would bring productivity and progress to their personal and professional development. The work with each of the participants was individual and confidential.

\section{PROCEDURE}

We had six months of observations and coach sessions in the form of individual work and private meetings with each participant applying all the methodological instruments for the data obtaining. This process included a final coaching module with the feedback from each participant and consultancy on a future vision of his/her self-development in entrepreneurship.

The first stage was an interview which consisted of different questions, targeting to understand the framework of shaping the entrepreneurial I-position (mission, values, strong and week sides, inner voices and critical incidents led to the choice of becoming the entrepreneur).

The second stage was mapping. The mapping instrument is targeting to discover the personal life way of the participant up to the moment of the research. The example of the mapping of one of the participants is shown in figure 1.

The timeline includes the ages and the short description of critical incidents that occurred with the participant and had a strong emotional impact and influence on his decision to become an entrepreneur. Above the line, the positive critical incidents are situated. Underlined there is a place for the critical incidents which the participant sees as negatives. The star shows the most important/crucial critical incident on forming of the entrepreneurial identity according to the opinion of the participant. The participants were provided with the instruction from the researcher; another part of it was done individually.

The next stage included using the Journey Plot. The process consisted of two steps - weekly individual work of the participant - at the end of each week the participant got the survey using Google forms with the questions according to his experience during the past week including any particular/important or critical incidents that happened during this period. Then each participant was evaluating the emotional impact of mentioned critical incidents using the scale 


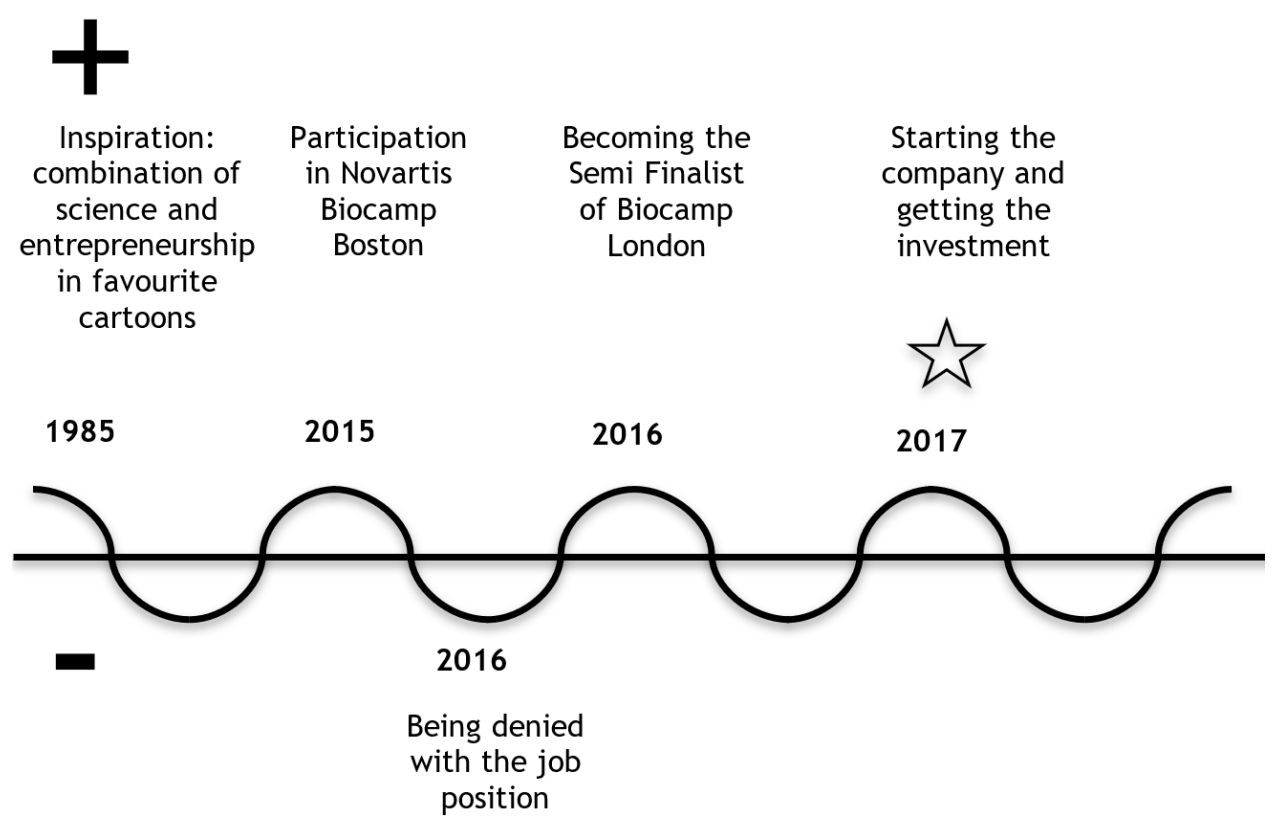

Figure 1. The Mapping, Participant J.

from +2 (positive) to -2 (negative). The second step was the monthly meeting when we discussed the results of the months using the interview which was recorded, transcribed, and then compared. The idea of frequent meetings had two purposes: to help the participants to develop his self-reflection skills and to help them not to miss any special occasion or event during this period of time. As the example, we can see the Journey Plot of the Participant N. (Figure 2).

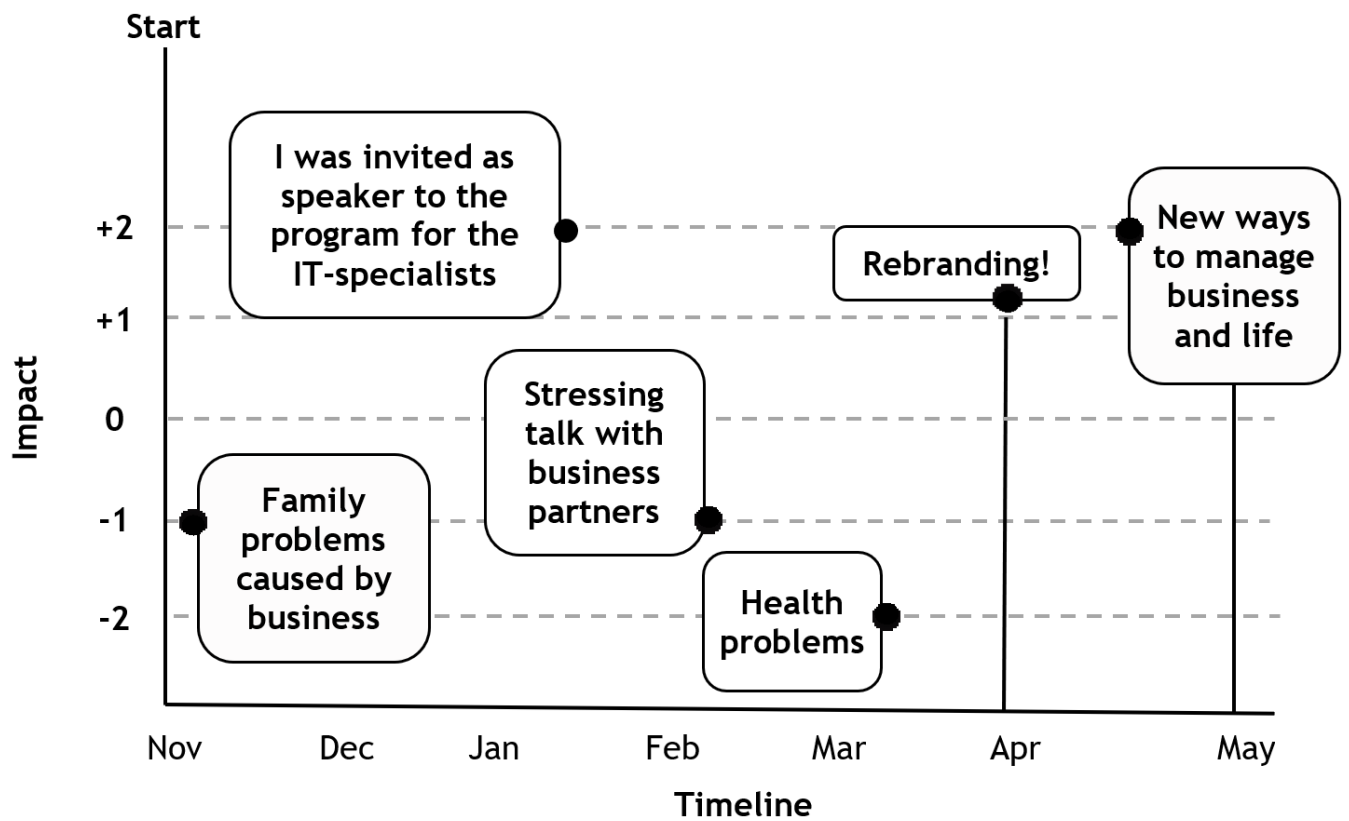

Figure 2. The Journey Plot. The analysis of the participant's trajectory. Participant N. 
Journey plot helped us to fix the main critical incidents leading the way of forming the entrepreneurial I-position; every event was characterized by feelings and emotional impact of each critical incident. During this process, we were discussing the inner voices interacting in each stage and the I-positions revealed by these events. This information allowed us to develop the Personal Position Repertoire (PPR) profile (Figure 3 ) in which the identity positions of the Participant L. were identified.

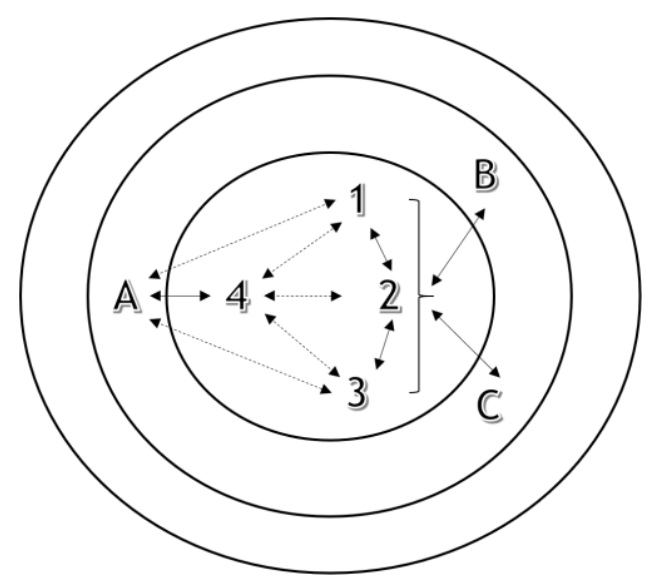

Intern (I)

(1) I-position: Leader

(2) I-position: Real me

(3) I-position: Achiever

(4) I-position: Dependent

\section{Extern (others-in-me)}

(A) My parents

(B) My husband

(C) My business coach
Outside (Community)

My parents' company

My internship company

My university

\footnotetext{
non-conflictive

conflictive relationships
}

Figure 3. Personal Position Repertoire of the Participant L.

Three circles presented in Figure 3 are showing different aspects of the interactions of I-position. The central circle is related to the intern side of Ipositions showing their perception of their entrepreneurial identity, their personal way of feeling of what they are, and which positions are related to their strategies. The circle in the middle is representing the aspect of "others-inme" when the inner voices of people who are important to the participant and whose voices are reflected in their behavior in different professional background. The third circle is related to the outside part of identity - to the community where the person belongs and which institutional vision influences the person's positioning, his or her self-understanding, his or her personal and 
professional views. All these circles combined together reflect different aspects of personal repertoire of I-positions.

At the beginning of the procedure, the participant was presented with a list of internal and external I-positions that were systematized according to the data obtained during the application of previous methods. Then L. chose those of them which she found belonging to her identity and more relative to her selfperception. After that, we were able to discuss the relationship between these I-positions which we characterized as non-conflictive (for example, the internal position defined as "achiever" and the external ("others in me" - "my business coach") and conflictive (for example, the internal position of "leader" and the external position "my parents").

The coaching session was organized once during the research process for each participant and had the target to finish the research and make it useful not only for the purposes of the research but also for the participants. The length of the coaching session was forty-five minutes approximately for each participant. It contained assuming of the final results, the feedback, the conclusions of the participants about their progress and changes in their entrepreneurial identity that the program brought into their life followed by a discussion of their new goals.

In Figure 4 the whole process of the research procedure from the start to the end of the research is shown.

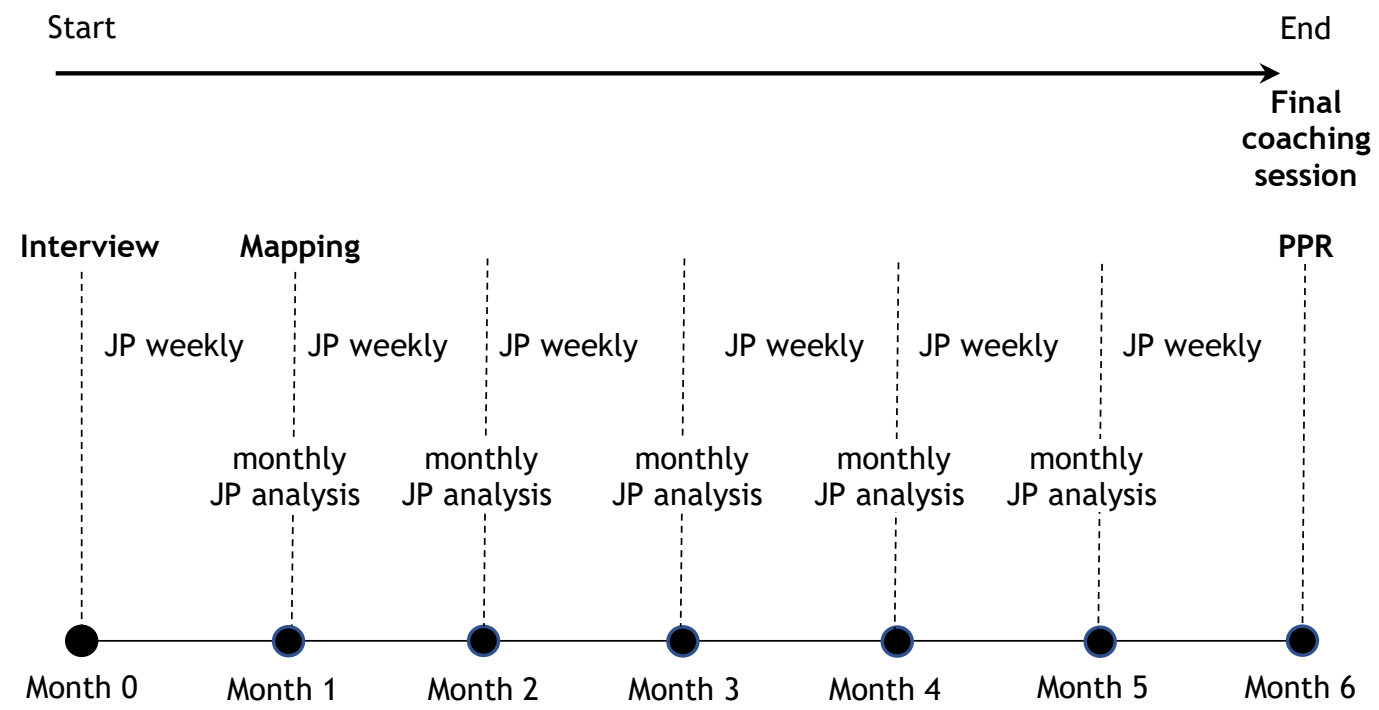

Figure 4. The whole process of the research procedure 


\section{DATA ANALYSIS}

All the mentioned tools were used for getting the complete profile of each participant and the profound case description. This research was mostly qualitative; however, some quantitative methods were also applied for the PPR method. Using qualitative methods for data analysis helped us with a detailed understanding of the participants' experience. For this reason, we used the classical grounded in analysis divided into the stages of identifying ideas repeated throughout the data and organizing ideas into broader themes, proposing an interpretation of the data (Price, 2019).

For the analysis of data obtained during the interview, we used the method of content analysis (Neuendorf, 2010). We had to adapt the method to the goals and needs of the current research, so we structured each answer into the table containing each category used for the final profile of the participant. Applying the mapping instrument, we have extracted the main critical incident using the o see the decision to become the entrepreneur. The journey plot instrument also helped us to collect data connected to the critical incidents of the participants, but in this case, we were fixing the situations which were connected to the process of the entrepreneurial identity within the research and participation in the program. For the PPR method we used the mixed technique of data obtaining, we analyzed the positional repertoire (this process was widely described before) and the correlations between the I-positions using the table of data helping to extract the range of the positions for each participant.

All data obtained during the research helped us to create the final matrix for each participant and to reveal the following categories:

- context of forming entrepreneurial identity (the background that we have discovered during our study that influenced other categories of identity formation);

- core I-position as a central I-position influencing the strategies of facing critical incidents and entrepreneurial behavior;

- missed I-position - I-position that is missing in the range of entrepreneurial I-positions and can be seen as a factor stopping the effective use of the proper strategies for facing critical incidents;

- desired I-position - I-position which is seen by the participant by the one that he/she wants to form for proper facing of critical incidents, effective entrepreneurial behavior and forming a balanced entrepreneurial identity; 
- inner voices that influence forming the entrepreneurial identity - the voices that construct "multivoicesness of self" and involved in the inner dialogues on different levels;

- main critical incident which influenced forming of the entrepreneurial identity during the Study and its influence on changes in I-positions of construction of entrepreneurial identity;

- crisis causing point - the situation or activity of the highest emotional impact on the person which became a starting point for the changes in identity

- point of growth - the factor or range of circumstances that helped the participant to face the critical incident properly and to choose "winning" strategy.

\section{RESULTS}

Based on the results, we were able to check all critical points influencing the changes of I-positions in the construction of the identity of young entrepreneurs.

Now we would like to pay attention to the final profile of each participant as it shows essential stages and highlighting the general processes of the forming of the entrepreneurial identity. The profiles of each participant show the variety of contexts which are shared among the entrepreneurs and explain the variety of I-positions.

\section{Results for the Participant L.}

Context of the forming the entrepreneurial identity: L. is a young entrepreneur who was growing within her family business. Now as she finished the university, she has plenty of possibilities such as becoming involved in her parents' business or starting her own company or as an additional option, starting the career in a big company with the perspective of becoming the part of their top management.

Core I-position, according to Study 1: Leader. L. is characterized as an active and motivated person; she likes to be involved in the team activities, believes that the shared vision can lead the company to better results and join people for achieving big goals.

Missed and desired I-position: Fighter. Being in the I-position of Leader was always easy for $L$. when she had the resources provided by her family. She could use the unlimited budgets and lead the team of people believing she got it her- 
self. For her, entrepreneurship was not about earning money or surviving in the competitive market, that was always provided by her parents; also her parents did not give her enough freedom of choice or let her make mistakes as they always knew they would do everything smarter thanks to their significant entrepreneurial experience. That is why I-position of the Fighter was blocked entirely. During the process of the study, we found out with L. that this was not only her missed position but also her desired I-position.

For now, I find just $10 \%$ of entrepreneurship in myself. I cannot measure by selling and getting, achieving what I want, and I need, I rather give up and ask for help from my parents... I just can give out and don't care what I get back what I understand is unbelievable in real business. But sometimes I become so goal-oriented to get what I need (save money, get a discount for my business, etc.) so I feel that skills in myself and I feel I should develop that hidden part of me (L., personal interview, November 2018).

Analyzing her Mapping, L. understood that she was always more satisfied with herself; she achieved something despite the circumstances. As we pointed that out, L. started self-reflection and made herself the challenges where she could act independently without the influence of her parents' opinion.

Inner voices that influence forming of the entrepreneurial identity:

We found out four different inner voices influencing L.: the first one was her parents' voice, this voice was always saying her that they love her no matter was happens, but she is not ready for taking her own decisions. This voice brought her nice feeling of coziness and calmness in her life but frustrated her with the idea of not being able to become a real entrepreneur and to take the responsibility of making her own mistakes. Another voice was "her husband's" voice that told her she should try to start her career in a big company and separate from the parents' business. This voice was challenging, but she enjoyed that part of herself as it gave her the hopes, she is strong enough to do that. During the study period, we noticed different stages of voice's influence and in some stages, L. was entirely sure she will start her career, in other situations she said, "she never can leave her parents' business as they need her very much." (L., personal interview, January 2019).

In this case, we see two more voices helping to achieve the balance and very closely related to this angle - the voice of her business coach and her voice of "real me" as $L$ called it herself. These voices were not contradictory for her as $L$ highlighted that the voice of her business coach was always telling her she is unique and can manage any challenge using her skills and talents. Her real voice always told her she could achieve anything she wants; we can see it as an ambitious voice. 
The main critical incident which influenced the forming of the entrepreneurial identity during the Study and the Crisis causing point:

During these six months, she participated in the contest for the vacancy for the big company where she could make the career of top-manager and progress professional development outside her parent's company. That was contradictory to "her parents" voice. However, L. decided to try to participate in the contest (here we see other three voices influence: her husband's voice, her business coach voice, and her "real me voice"). When we analyze that we can see that the crisis causing point was in the field of high ambitions and the lack of responsibility, practical skills, and experience in entrepreneurship. However, during the contest in the big company, L. managed to show her leaders skills, had a variety of challenges that were driving her entrepreneurial spirit, she was acting outside of the situation of her family business and was free to act how she wanted. As a result, she was chosen for the position in the company but finally denied it ("parents' voice influence). However this critical incident became very positive for her in different aspects: first, her parents were very impressed by her success and changed her point of view on her status in the company and proposed her to manage the marketing department in their family business with the perspective of managing the whole company in future, second, for L. decision finally became very easy to take, she understood how difficult was for her parents to build the successful business. However, one of the most crucial conclusions for her was that she saw hired people in a big company acting as entrepreneurs, believing entirely in their business. It completely changed her understanding of her entrepreneurial I-position and role in her company including the level of responsibilities she took.

Point of growth and final results: As the result for Participant L. we consider further points: We could see the result of using different psychological tools that lead to: understanding actual I-position and working on missing I-position strategies, separating of the inner voices and their meanings and training to listen and find the "real me" voice, working on facing the critical incident which became positive and a point of growth instead of the perception of harmful and disruptive. Through the self-reflection and going passing the critical incident, L. came to a better understanding of herself as a young entrepreneur.

I am drifting now, and I want to change everything in my behavior regarding management and my life in general. How I plan to change: First - Do not be afraid of anything, but take and do, without inventing any excuses; second, Give more time to work and your results in management; third, I will build up a clear time management system in order to have time for everything and not to postpone anything. (L., personal interview, November 2018). 
This case can become a practical example of a forming the entrepreneurial identity of the person growing within a family business.

In table 2, you can see the final profile of the Participant $L$.

\section{Results for the Participant J.}

Context of the forming the entrepreneurial identity: $\mathrm{J}$. is moving from the working within the big pharmaceutical company to creation of his own high-technological business. He was always dreaming of becoming an entrepreneur, characterizes himself as a person "permanently creating new ideas which could improve the world" (J., personal interview, September 2018).

That inspired him to create his own business. After a few trials, he got the investment from a very famous venture capital company which became a starting point for the functioning of his business.

Core I-position according to Study 1: Innovator. It is characterized by innovative thinking, the creation of innovative products. As he mentioned during the first interview: "For me is very important that my business model has no analogs on the market as I am targeting to change people's lives with my products and to create the new solutions for "making the world a better place to live" (J., personal interview, September 2018).

Missed and desired I-position: Fighter. Being an innovator, J. enjoys his kind of activities, focuses on his success, and tries to escape the challenges. He shows himself an excellent businessman for the extended strategical plans, but he actually cannot cope with the real problems which he faces in everyday life of the entrepreneur. So, the lack of strong will in sorting out the real-time situations causes him the problems and does not provide enough productivity. During the coaching sessions, we found out that problems that are typical for any business make him feel deconcentrated, loose the interest in the job, and giving up some projects he was aiming to finish. These personal characteristics could be the result of the long period of working as a hired person where he did not need to take the responsibility on himself for the whole business and its stable position on the market. J. would like to be more effective in achieving 
the short-term goals which would provide him and his business more stability and would allow concentrating on future innovative ideas.

Inner voices that influence forming of the entrepreneurial identity: Between the inner voices for J., we can see the voices of his family members whom he characterizes as more influencing his business way of thinking and the voices of another dimension which we decided to call as "voices of the illusions" and "voices of the reality." Describing the voices of his family members he says: "My mother's voice always tells me to do the proper things as my wife's voice says, "do the things properly" And I don't find it contradictory, I feel that both ways of thinking helping me to get to better me and to see my business in more holistic way" (J., personal interview, January 2019). We found out that this combination of the voices is quite harmonic for his identity and helps him to be productive in solving the problems. On the other hand, the voices of reality and illusions are quite contradictory and lead to a personal crisis very often. This illusion voice shows future as a non-problematic field full of opportunities and great achievements, but the reality voice (which J. tries to escape as much as possible) says that everyday efforts are not enough for productivity.

The main critical incident which influenced the forming of the entrepreneurial identity and the crisis causing point: The main critical incident for participant $\mathrm{J}$ was his participation in the world-famous acceleration program for the innovative high-tech business. That became a starting point for forming his identity as an entrepreneur and brought many challenges. As he said during one of the coach sessions: "This event became crucial for me, I was always dreaming of developing my idea and becoming a businessman, but when it happened it brought not just the joy but too much stress and worries too" (J., personal interview, September 2018). During the coaching sessions, we found out that this success made him very sure in himself but at the same time, put too much pressure. Actually, he didn't know how to be the real businessman, but the speed of the program and the requests of the investor were so high that he hardly was managing with all the tasks, felt exhausted as he didn't get accustomed to such life rhythm, but he couldn't show that to the members of his team or the investor. More profound research showed that he was concentrated on the process more than on the result and led not only to the problems in the fast-growing business but also influenced his psychological state. However, he successfully finished the program, and this critical incident became a start of his understanding and forming his entrepreneurial identity targeting to focus on the results and providing a wider variety of personal techniques for facing the challenges. 
Point of growth and final results: As a result for the Participant J. we consider further points: We could see the process of revealing and understanding the entrepreneurial identity which was actually shaped during the previous years of creating his idea and the process was speedup by the critical incident which became the crucial line between being "me as a person with innovative ideas" and "me as a person leading my own business" for the participant. Also, we consider this case as a very interesting from the point of view of adding new type of entrepreneurial voices that can be quite typical for the young entrepreneurs - the voices of the reality versus voices of illusions which young entrepreneurs have to start their business and to have the impression that the business world is just the world of success and vast opportunities. The fact of participation in the business accelerator was an excellent success for starting the business, but it showed a real lack of psychological support and revealed the problem that the unformed identity of a young entrepreneur can influence the productivity of his business.

This case can become a practical example of a forming the entrepreneurial identity of the person who started his own company after working as a hired person and running his own business after participation in the accelerator or business incubator or any other kind of such type of programs (table 3 ).

\section{Results for the Participant $\mathrm{H}$.}

Context of the forming the entrepreneurial identity: $\mathrm{H}$. is a cofounder of the company working in the area of Big Data. Before starting his business, $H$. was into multiple projects in which he was training his professional skills. H. works hard out of regular working hours (which is typical for the startups) and tries to get stronger business positions on the competitive market, in the same time he is going through difficulties dealing with his partners.

Core I-position according to Study 1: Fighter. H. showed himself as a fighter focused on the surviving in a competitive business world. Since his childhood, he saw his parents

\begin{tabular}{ll}
\hline Variable & \multicolumn{1}{c}{ Characteristics } \\
\hline Context & $\begin{array}{l}\text { From hired person to } \\
\text { the own high-tech busi- } \\
\text { ness }\end{array}$ \\
$\begin{array}{l}\text { Core- I- } \\
\text { position }\end{array}$ & Innovator \\
$\begin{array}{l}\text { Missing I- } \\
\text { position }\end{array}$ & Fighter \\
$\begin{array}{ll}\text { Critical } \\
\text { Incident }\end{array}$ & $\begin{array}{l}\text { Getting the investment } \\
\text { and participation in VC } \\
\text { acceleration program } \\
\text { “Reality" voice opposite } \\
\text { to "Illusional” voice }\end{array}$ \\
\hline
\end{tabular}

Table 3. The final profile of Participant J. 
working hard to provide a satisfactory family level of life, and this model was trained during these years. For him being highly competitive is very important. He says he can only count on himself and trust only himself. Although being a very experienced professional with a flexible mind as an entrepreneur, he shows himself as a conservative, focused on competition and surviving on the business market.

Missed and desired I-position: Opportunist. Conservative model of business connected to the dominating I-position of the Fighter does not allow $\mathrm{H}$. to be flexible enough to achieve his big goal - becoming the local market leader in his area. During the coach sessions, step by step we were going from external position of claiming, e.g., "my business is not productive at all" we came through the internal position "I'm not productive as a businessman", "I can't do it anymore, I'm so exhausted", "I'm so tired doing my business" (H., personal interview, November 2018). So, the focus was changed to the entrepreneurial identity of $\mathrm{H}$. where we found out that his position of fighter exhausted him, and he would like to see his business as a world of opportunities and selfdevelopment. This idea helped $\mathrm{H}$. to focus on the idea of a rebranding of his business and changing his tactics, and he realized that during the whole six months of the research.

Inner voices that influence forming of the entrepreneurial identity: We found out that $\mathrm{H}$. has two leading inner voices and, in his case, in comparison with other participants these voices are not connected to the family members or any people (this fact could be connected to the dominating position of fighter). During the interview, we saw the exact difference between self-perception of being "myself" and "being a good entrepreneur." During one of the coach sessions, H. says: "If I use your terminology and call it "voices" I would say that the voice of "myself" is always claiming on feeling stressed and tired and being not satisfied by his way of managing the business" $(\mathrm{H}$., personal interview, November 2018). On the other hand, $\mathrm{H}$. is conducted by the voice by the real entrepreneur aiming to lead his business to the top position and productivity working hard to be able to provide his family and his team with good financial results. These voices look quite contradictory to each other and show a lack of harmony in the identity profile of the entrepreneur.

The main critical incident which influenced the forming of the entrepreneurial identity and the crisis causing point: During six months of the study session to session, we tried to focus $\mathrm{H}$. on his identity more than just on business productivity aiming to help him to realize his own needs and wishes and lead to the broader vision of his business which could help to change his business model. In one of the stages of our research $\mathrm{H}$. came to the conclusion that this way of 
managing business is just bringing him constant stress and tension: "I understood that on in spite the fact that I work more than sixty hours a week over the last five years on the 1st of may I am not considered a worker. So, the whole theory of labor division does not apply anymore, and the capital (intellectual) does not belong to me, it is on employees' heads. To be an entrepreneur, you have to accept this challenge deeply in your heart."

In the meantime, one of the partners proposed him to change the business model and add some more services that need fewer efforts and could bring more financial results. This decision was significant to $H$. and led to stopping cooperation with one of the co-founders. That was a tough decision for $\mathrm{H}$., but as he mentioned himself, "the situation could not be worse" $(\mathrm{H}$., personal interview, November 2018). During this time, he got very sick, and that was the time for re-thinking and reflecting the situation. The need of the fast and changing decision in the line of his business became crucial and caused to the crisis causing point made by two inner voices of "me as a person" and "me as an entrepreneur" get together and understand the priority of each role.

Point of growth and final results: As a result, for the Participant $\mathrm{H}$., we consider further points: contradictory nature of two types for many of young entrepreneur voices - "me as a person" and "me as an entrepreneur" caused by a high level of rhythm, stress, and tension of responsibility. It was also important to find out how critical incidents could become a real psychosomatic factor leading to sickness. Re-thinking and re-understand of the situation, overcoming the challenges oppositely can become a significant point of growth. We can see that the psychological support for the participant played a vital role in shaping the identity of the entrepreneur.

This case shows the existence of a strong relationship between the entrepreneurial identity and business model and can become a practical example of a forming the entrepreneurial identity for the startup entrepreneurs dealing with high level of stress and tension. It also clearly demonstrates how focusing on the person, and more in-depth understanding of his entrepreneurial iden-

\begin{tabular}{ll}
\hline Variable & Characteristics \\
\hline Context & $\begin{array}{l}\text { From multiple projects to } \\
\text { starting a business with the } \\
\text { partners }\end{array}$ \\
$\begin{array}{l}\text { Core } \\
\text { I-position }\end{array}$ & Fighter \\
$\begin{array}{l}\text { Missing/ } \\
\text { desired }\end{array}$ & Opportunist \\
I-position & $\begin{array}{l}\text { Changing the business } \\
\text { Critical }\end{array}$ \\
Incident & $\begin{array}{l}\text { model to help the business } \\
\text { to survive }\end{array}$ \\
Voices & $\begin{array}{l}\text { "Me as an entrepreneur" } \\
\text { vs. "Me as a person." }\end{array}$ \\
$\begin{array}{l}\text { Crisis } \\
\text { causing } \\
\text { point }\end{array}$ & $\begin{array}{l}\text { Stress and tension in busi- } \\
\text { ness leading to worse } \\
\text { health }\end{array}$ \\
\hline
\end{tabular}

Table 4. The final profile of Participant $\mathrm{H}$. 
tity helps to improve the business strategies and influence on the productivity of the whole business (table 4).

\section{Results for the Participant N.}

Context of the forming the entrepreneurial identity: $N$. started from freelance as a consultant and moved to the idea of her own business in the consulting area. Her main intention in this period of life is to find and understand herself as an entrepreneur, to shape her identity on practice while realizing her talents, potential, and way of entrepreneurial behavior.

Core I-position according to Study 1: Opportunist. Shaping her professional identity as a freelancer $\mathrm{N}$. shows herself as a constant resource finder. $\mathrm{N}$. describes what is it be an entrepreneur in her opinion as to:

Design, initiate and develop a business idea, which can be more or less innovative, and apply all those necessary strategies (oriented to different levels: product, processes, human resources, company culture, etc.) to guarantee a progressive augment but sustainable of the quality of the product/services that you offer as the economic or social benefits it provides. (N., personal interview, November 2018)

During the interview, N. highlighted that starting her own business is the best way to build a successful career in actual economic conditions in comparison with the option of finding the proper job. She is oriented to the market needs and can easily see what is of high demand for the client. N. is an excellent communicator and can quickly feel the needs of her clients as well as building the networks and constructing long-term client relationships. Constant feedback from the clients, communications, and clients' recommendations of her services from one to another are her most valuable factors in the creation of her own business. An interesting fact is that $\mathrm{N}$. sees growing from freelance to her own business as a new opportunity for her personal life way.

\section{Missed and desired I-position: Leader}

Working in the status of the freelancer shaped N. as an excellent professional but actually isolated her from a team job and partnerships. She finds taking responsibility for other people (which is a part of any business) as a very stressful factor. N. is useful in creating her life vision but is far from seeing a complete business model that would help her to move to another level. Leadership seems inspiring for her, but she feels she is not ready for that and still needs to develop a lot of personal and professional competences to complete her profile of psychological strategies as an entrepreneur. 
Inner voices that influence forming of the entrepreneurial identity: The leading inner voice for $\mathrm{N}$. is her brother's voice, who is a source of her inspiration, is a constructive voice helping her to believe that moving her I-position from the freelancer to an entrepreneur will be a success. Another interesting fact is that N. has a voice of her friend who is quite skeptical about entrepreneurship and shows $\mathrm{N}$. the disadvantages of this career way as well as persuading her not to get too hard into the process: "One of the voices is the voice of my friend he is actually an anti-entrepreneur, and he says that I should focus on studying things and enjoying my life, so that also supports me in many moments" (N., personal interview, November 2018).

Analyzing these two voices $\mathrm{N}$. did not find them contradictory as she was insisting that the voice of her friend is not a demotivating factor in this case but a reminder about a complete and harmonic way of life (we could see the example of the lack of the life-job balance in the previous case of the Participant $\mathrm{H}$.

The main critical incident which influenced the forming of the entrepreneurial identity and the crisis causing point: The critical incident of the higher impact for N. during our study was the transformation of her idea of being "by herself" and starting to think like a real entrepreneur. In the beginning, she had a company started together with a partner who did not have the same vision as she. It led to the conflict, and the business model was not realized. This case was connected to the financial part of doing business which $\mathrm{N}$. find as the most stressful aspect of being an entrepreneur. That stops her from complete transportation into a real entrepreneur and does not allow her to feel her identical profile as a complete one. "I do not consider myself as a good entrepreneur because I did not dedicate enough time to the development of my business right now. Also, I am not that good in financial aspects. I see that I am not so good at working with a team and to take responsibility for them," says $\mathrm{N}$. during her interview (N., personal interview, November 2018).

Point of growth and final results: In the case of N., we can see some points of growth: - understanding her weak sides as an entrepreneur (what is missing) and the high need for external motivation to get from one phase to another. This case is very representative in showing the harmonic nature of the family voice in shaping the entrepreneurial identity (here we can make the comparison with the case of the Participant L. whose family voice was acting as contradictory). It also highlights the importance of the responsibility as a challenging factor for young entrepreneurs. Here we can compare it with the case of Participant $J$. - being an entrepreneur seems to be attractive until the real challenges start. However, in the case of N., we notice how the lack of leader strategies influence the readiness for starting the business. This case can be- 


\begin{tabular}{|c|c|}
\hline Variable & Characteristics \\
\hline Context & $\begin{array}{l}\text { From freelance to starting } \\
\text { a business in the consulting } \\
\text { area }\end{array}$ \\
\hline $\begin{array}{l}\text { Core } \\
\text { I-position }\end{array}$ & Opportunist \\
\hline $\begin{array}{l}\text { Missing/ } \\
\text { desired } \\
\text { I-position }\end{array}$ & Leader \\
\hline $\begin{array}{l}\text { Critical } \\
\text { Incident }\end{array}$ & $\begin{array}{l}\text { From dealing with business } \\
\text { partners to own business }\end{array}$ \\
\hline Voices & $\begin{array}{l}\text { "Family" voice as an in- } \\
\text { spiring voice }\end{array}$ \\
\hline $\begin{array}{l}\text { Crisis } \\
\text { causing } \\
\text { point }\end{array}$ & $\begin{array}{l}\text { Being by myslelf opposite } \\
\text { to taking responsibility }\end{array}$ \\
\hline
\end{tabular}

Table 5. The final profile of Participant N. come an example of moving from the I-position of the professional/ freelancer to the I-position of an entrepreneur which is quite common for the way of starting own business (table 5 ).

\section{DISCUSSION}

The research shows the variety of scenarios of forming entrepreneurial identity using four different types of entrepreneurial I-positions, strategies, and feelings of each participant according to the influence of inner voices and facing critical incidents during their everyday personal and professional life. The change

in entrepreneurial I-positions occur with the influence of numerous factors from the understanding of the participant's current core I-position to the transition of understanding, which is missed, and which one is desired. In our opinion these changes were provoked by two groups of factors - first, is the development of self-understanding of the identity of participants using the set of tools provided by the research and the second one is facing critical incidents which lead to forming the entrepreneurial identity.

Applying the wide range of instruments helped us systematically understand the process and the key factors which led to the changes of entrepreneurial Ipositions and the construction of entrepreneurial identity. We started with the Survey for Entrepreneurs on Critical Incidents applied during previous studies which revealed the core I-position (e.g., Leader), then applying other methods and instruments as Interview, Mapping, Journey plot, and PPR, we could understand how this position was formed, which critical incidents led to its forming and if this core I-position is adequately suiting to facing main critical incidents and provides a balanced identity to the person. Beside that, we could see that inner voices (e.g., "real me" voice) could be contradictory or harmonic, helping the person to develop his identity. Also, the relation between the categories "missed" and "desired" I-positions showed us it's dynamic nature. So, starting from the core I-position (e.g., fighter) the person can see the so-called "week" points of this I-position strategies for effectiveness in facing critical incidents, we come to the understanding of "desired" I-position which can add 
personal position repertoire and provide the productivity of strategies in facing future critical incidents as well as forming balanced entrepreneurial identity.

We consider that forming of entrepreneurial identity should include following aspects: a) understanding of the personal way and critical incidents that led the person to choose the profession of an entrepreneur, b) realizing their dominating I-position as well as missing and desired I-position for the balanced and flexible application in a different kind of situations, c) ability of self-reflection and transforming negative critical incidents into the points for growth, d) getting to the harmonic identity of "me as an entrepreneur."

In a practical way, we can see "Me" as a complete and balanced when the following conditions are satisfied: a) the person has a wide range of I-position flexibly applying them according to the circumstances or problems, b) the dominating I-position becomes a strong side of the entrepreneurial identity and the desired I-position leads to new challenges and targets, c) the inner voice can be understood and the "real me" can be heard by the person able to find his independent solution for each situation.

The research showed a solid connection between personal and professional life and self-perception of the entrepreneurs. The family and personal psychological aspects were tightly connected to the progress in business and were helping or, in another case, slowing down their professional progress. So, the family or friends voices were understood as contradictory or encouraging voices and led to the crisis in some cases. Positive and negative critical incidents were leading to the crisis in the case when the person's identity was not formed yet, besides while developing their entrepreneurial identity participants trained themselves to understand each critical incident as a point of growth. Thus, self-reflection became a habit for the participants.

In every case, we saw the changing I-positions during the period of the study or even transposition while forming the identity and facing personal and professional challenges. Also, we saw that the coaching (not only research) process had a very high impact on the identity formation of each participant.

Applied tools (including mapping, journey plot, PPR and structured interview together with the coaching approach) showed a productive effect on the participants' identity-forming and could be used for the designing of the program of developing of the entrepreneurial identity which would include such categories as working with inner voices, I-positions, and personal strategies, critical incidents as crisis causing points and points of potential growth. 


\section{CONCLUSIONS}

We consider that this Study was focused only on four representatives of different entrepreneurial I-positions. On the other hand, the participants showed a variety of cases and scenarios of forming the entrepreneurial identity in most typical contexts, including family business, starting their own business after working for the company or as a freelance. The research showed a high interest and deep involvement of the participants, as well as a lack of psychological support and a high need of young entrepreneurs for a profound discussion of their feelings, thoughts and critical incidents as the business world, does not accept mistakes which creates a continuous pressure to succeed. We can see that the implication of the set of the tools used in the psychological practice and Dialogical Self Theory helped to make the process systematic, clear and multi-level showing as well as the progress of participants on every stage as their own personal and professional achievement in each part of the Study. Forming the entrepreneurial identity is a crucial stage on a personal and professional way. Otherwise, the business becomes meaningless and causes the psychological crisis to the entrepreneurs in the future. One of the essential skills - self-reflection and ability to recognize their inner voices, face critical incidents using proper I-position and developing flexibility, turn crisis causing points into the points of growth helped the participant to form their entrepreneurial identity and to create the new goals of personal and professional growth.

The process of the shaping identity of young entrepreneurs can be potentially applicated to a more experienced audience with the entrepreneurs on other stages of their career (more than two years of experience, very experienced or even entrepreneurs who already retired but the target to become the mentors). These cases will become the basement of the program for the development of the identity of entrepreneurs based on critical incidents. The study leads to the creation of a unique psychological program for young entrepreneurs at an early stage of their business career.

\section{REFERENCES}

Bartlett, Lesley \& Vavrus, Frances (2017). Rethinking Case Study Research. New York: Routledge. https://doi.org/10.4324/9781315674889

Burnard, Pamela (2012). Rethinking creative teaching and teaching as research: Mapping the critical phases that mark times of change and choosing as learners and teachers of music. Theory into Practice, 51(3), 40-52.

Hermans, Hubert J. (2001). The construction of a Personal Position Repertoire: Method and practice. Culture \& Psychology, 7(3), 323-366.

https://doi.org/10.1177/1354067x0173005 
Hermans, Hubert (2006). The dialogical approach to counselling theory, research, and practice. Abingdon, Oxfordshire: Routledge.

Hermans, Hubert J. (2008). How to perform research on the basis of Dialogical Self Theory? Introduction to the special issue. Journal of Constructivist Psychology, 21(3), 185-199. https://doi.org/10.1080/10720530802070684

Hermans, Hubert J. (Ed.) (2016). Assessing and Stimulating a Dialogical Self in Groups, Teams, Cultures, and Organizations. Switzerland: Springer. https://doi.org/10.1007/978-3-319-32482-1

Hermans, Hubert (2018). Society in the self: a theory of identity in democracy. New York, NY: Oxford University Press.

Hermans, Hubert \& Gieser, Thorsten (2011). Handbook of Dialogical Self Theory. Cambridge: Cambridge University Press.

Hermans, Hubert \& Hermans-Konopka, Agnieszka (2012). Dialogical self theory. Cambridge: Cambridge University Press.

Hermans, Hubert; Kempen, Harry \& Van Loon, Rens. (1992). The dialogical self: Beyond individualism and rationalism. American Psychologist, 47(1), 23-33. https: / / doi.org/10.1037//0003-066x.47.1.23

Kluger, Avraham N.; Nir, Dina \& Kluger, Yuval. (2008). Personal Position Repertoire (PPR) from a Bird's Eye View. Journal of Constructivist Psychology, 21(3), 223-238. https://doi.org/10.1080/10720530802071518

Monereo, Carles (Coord.) (2015). PISA como excusa. Repensar la evaluación para cambiar la enseñansa [translation: PISA as an excuse. Rethink evaluation to change teaching]. Spain: Graó.

Monereo, Carles (2017). The role of critical incidents in the dialogical construction of teacher identity. Analysis of a professional transition case. Revista Akadèmeia, 16(2), 49-75.

Monereo, Carles (2019). The role of critical incidents in the dialogical construction of teacher identity. Analysis of a professional transition case. Learning, Culture And Social Interaction, 20, 4-13. https://doi.org/10.1016/j.lcsi.2017.10.002

Monereo, Carles; Weise, Crista \& Álvarez, Ibiz M. (2013). Cambiar la identidad docente en la Universidad. Formación basada en incidentes dramatizados [Changing university teachers identity: Training based on dramatized incidents]. Infancia \& Aprendizaje, 36(3), 323-340.

Neuendorf, Kimberly. (2010). The content analysis guidebook. Thousand Oaks, Calif.: Sage Publ.

Price, Paul C. (2019). Research Methods in Psychology - Simple Book Production. [online] Opentextbc.ca. Available at: https://opentextbc.ca/researchmethods/

Ruohotie-Lyhty, Maria (2013). Struggling for a professional identity: Two newly qualified language teachers' identity narratives during the first years at work. Teaching and Teacher Education, 30, 120-129.

Segal, Gerry; Borgia, Dan \& Schoenfeld, Jerry (2005). The motivation to become an entrepreneur. International Journal of Entrepreneurial Behavior \& Research, 11(1), 42-57. https://doi.org/10.1108/13552550510580834 
Valencia, Alina \& Monereo, Carles (2019). Identidad emprendedora y identificación de los incidentes críticos en la actividad profesional del emprendedor. In Jesus de la Fuente Arias, Manuel Vera Martínez, Manuel Aleixandre Rico \& José M. Martínez Vicente (Eds.), Innovación y emprendimiento en psicología (p. 7-14). Almería: Editorial Universidad de Almería

Van Loon, Rens (2010). The dialogical leader. Developing leaders for the future. The Netherlands: Deloitte.

Van Loon, Rens (2018). Creating Organizational Value Through Dialogical Leadership. Switzerland: Springer International Pu.

\section{ALina VALENCia}

PhD, Researcher of the SINTEdi and IdentitES scientific groups, business consultant, CEO of the "A-line" consulting agency, leader of the project "Competence platform", psychologist, business coach.

consulting@a-line-art.com

\section{FORMATO DE CITACIÓN}

Valencia, Alina (2020). The Changes of the Entrepreneurial Identity: Case Study. Quaderns de Psicologia, 22(2), e1574.

http://dx.doi.org/10.5565/rev/qpsicologia.1574

\section{HISTORIA EDITORIAL}

Recibido: 24-09-2019

$1^{\mathrm{a}}$ revisión: 11-06-2020

Aceptado: $22-07-2020$

Publicado: 31-08-2020 